PNNL-22238

U.S. DEPARTMENT OF

ENERGY

Prepared for the U.S. Department of Energy

under Contract DE-AC05-76RL01830

\title{
Global Threat Reduction Initiative Fuel Thermo-Physical Characterization Project: Sample Management Plan
}

\author{
A.J. Casella \\ M.M. Pereira \\ F.H. Steen
}

January 2013

Pacific Northwest

NATIONAL LABORATORY

Proudly Operated by Battelle Since 1965 


\title{
DISCLAIMER
}

This report was prepared as an account of work sponsored by an agency of the United States Government. Neither the United States Government nor any agency thereof, nor Battelle Memorial Institute, nor any of their employees, makes any warranty, express or implied, or assumes any legal liability or responsibility for the accuracy, completeness, or usefulness of any information, apparatus, product, or process disclosed, or represents that its use would not infringe privately owned rights. Reference herein to any specific commercial product, process, or service by trade name, trademark, manufacturer, or otherwise does not necessarily constitute or imply its endorsement, recommendation, or favoring by the United States Government or any agency thereof, or Battelle Memorial Institute. The views and opinions of authors expressed herein do not necessarily state or reflect those of the United States Government or any agency thereof.

\author{
PACIFIC NORTHWEST NATIONAL LABORATORY \\ operated by \\ BATTELLE \\ for the \\ UNITED STATES DEPARTMENT OF ENERGY \\ under Contract DE-AC05-76RL01830
}

Printed in the United States of America
Available to DOE and DOE contractors from the Office of Scientific and Technical Information,
P.O. Box 62, Oak Ridge, TN 37831-0062;
ph: (865) 576-8401
fax: $(865)$ 576-5728
email: reports@adonis.osti.gov

\begin{abstract}
Available to the public from the National Technical Information Service, U.S. Department of Commerce, 5285 Port Royal Rd., Springfield, VA 22161 ph: (800) 553-6847 fax: $(703) 605-6900$ email: orders@ntis.fedworld.gov online ordering: http://www.ntis.gov/ordering.htm
\end{abstract}

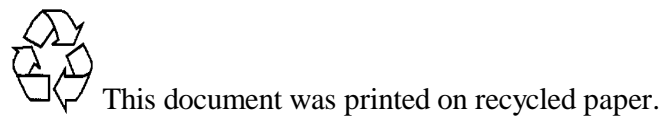




\title{
Global Threat Reduction Initiative Fuel Thermo-Physical Characterization Project: Sample Management Plan
}

\author{
A.J. Casella \\ F.H. Steen \\ M. M. Pereira
}

January 2013

Prepared for

the U.S. Department of Energy

under Contract DE-AC05-76RL01830

Pacific Northwest National Laboratory

Richland, Washington 99352 


\section{Revision Log and Approvals}

\section{GTRI: Fuel Thermo-Physical Characterization Project}

\begin{tabular}{|c|c|c|c|}
\hline Rev. No. & Date & Describe Changes & Pages Changed \\
\hline 0 & $02 / 07 / 2013$ & Initial release page change N/A & N/A \\
\hline
\end{tabular}

\begin{tabular}{|l|c|c|}
\hline \multicolumn{1}{|c|}{ Name and Title } & \multicolumn{1}{c|}{ Approvals } & Date \\
\hline $\begin{array}{l}\text { Fran Steen, } \\
\text { Author }\end{array}$ & $\begin{array}{c}\text { Mario Pereira per ERICA Information Release Number } \\
\text { PNNL-22238 }\end{array}$ & $02 / 07 / 2013$ \\
\hline $\begin{array}{l}\text { Doug Burkes, } \\
\text { Principle Investigator } \\
\text { Independent Reviewer }\end{array}$ & See ERICA Information Release Number PNNL-22238 & $02 / 07 / 2013$ \\
\hline $\begin{array}{l}\text { Bruce Slonecker, } \\
\text { Quality Assurance Manager }\end{array}$ & ERICA Information Release Number PNNL-22238 & $02 / 08 / 2013$ \\
\hline $\begin{array}{l}\text { Mario Pereira, } \\
\text { Project Manager }\end{array}$ & ERICA Information Release Number PNNL-22238 & $02 / 07 / 2013$ \\
\hline Note: Document approvals were received via ERICA Information Release Number PNNL-22238 \\
\hline
\end{tabular}




\section{Acronyms and Abbreviations}

AEA

CSM

DSC

EDS

GTRI

ICP-MS

ID

INL

LEU

LFA

$\mathrm{OM}$

PI

PIE

PNNL

QA

RMT

RPL

SAL

SEM

SFO

TG/DTA-MS

TI

TIMS
Alpha Energy Analysis

Cognizant Space Manager

Differential Scanning Calorimetry

Energy Dispersive Spectrometry

Global Threat Reduction Initiative

Inductively Coupled Plasma-Optical Emission Spectroscopy

Identification

Idaho National Laboratory

Low Enriched Uranium

Laser Flash Analysis

Optical Microscopy

Principal Investigator

Post Irradiation Examination

Pacific Northwest National Laboratory

Quality Assurance

Radioactive Materials Tracker

Radiochemical Processing Laboratory

Shielded Analytical Laboratory

Scanning Electron Microscopy

Shielded Facilities Operations

Thermogravimetry and Differential Thermal Analysis with Mass Spectroscopy Test Instruction

Thermal Ionization Mass Spectrometry 


\section{Table of Contents}

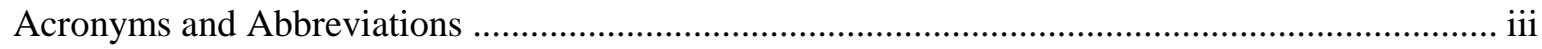

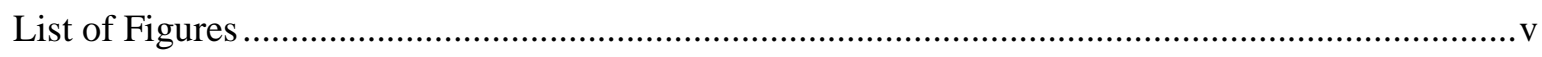

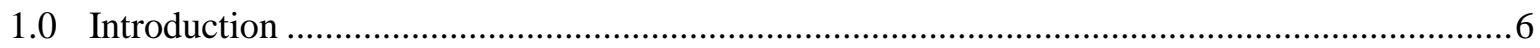

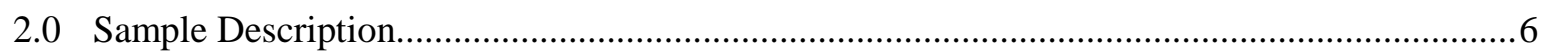

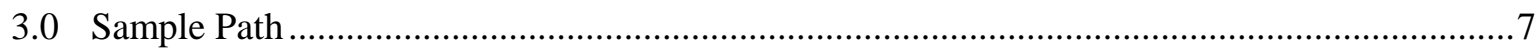

3.1 Sample Receipt - Shielded Analytical Laboratory …............................................... 8

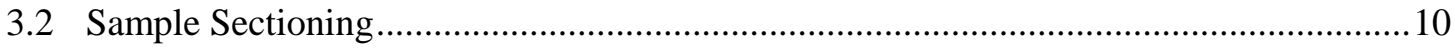

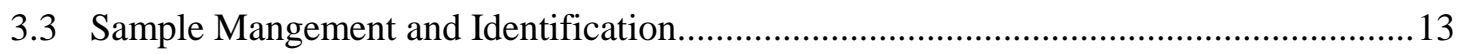

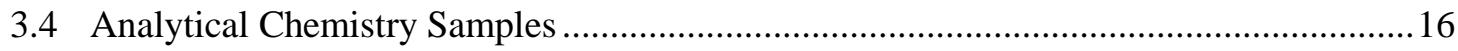

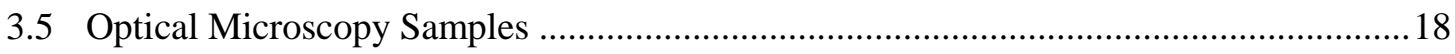

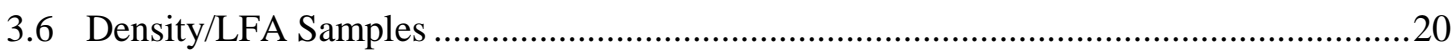

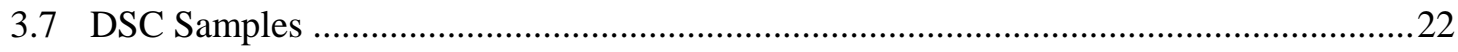

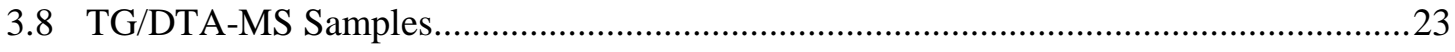

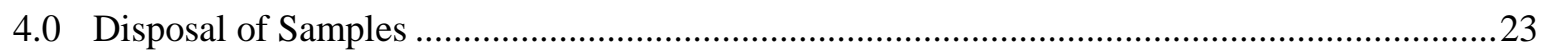




\section{List of Figures}

Figure 2.0. Typical Fuel Foil Cross-Section (dimensions are in inches) ......................................6

Figure 3.0. Flow Diagram for Sample Paths and requirements for U-Mo fuel elements ................. 7

Figure 3.1. Path and criteria for sample receipt and transfer to SAL Hot Cell .............................. 9

Figure 3.2A. Segmentation of samples for LFA, pycnometry, OM, DSC, and analytical

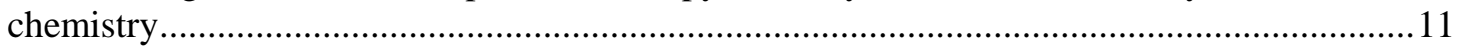

Figure 3.2B. Segmentation of samples for TG/DTA-MS ....................................................... 12

Figure 3.3A. Planned nomenclature for LFA, pycnometry, OM, DSC, and analytical chemistry

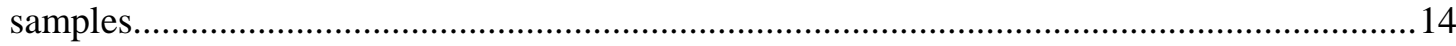

Figure 3.3B. Planned nomenclature for TG/DTA-MS samples............................................... 15

Figure 3.4. Path and criteria for analytical chemistry samples ................................................... 17

Figure 3.5. Path and criteria for OM samples ........................................................................ 19

Figure 3.6. Path and criteria for density and LFA samples........................................................21

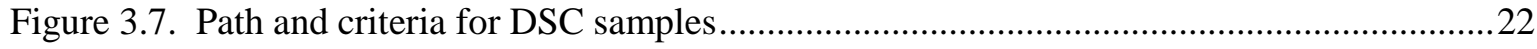

Figure 3.8. Path and criteria for DTA/TG-MS samples.........................................................23 


\subsection{Introduction}

This sample management plan provides guidelines for sectioning, preparation, acceptance criteria, analytical path, and end-of-life disposal for the fuel element segments utilized in the Global Threat Reduction Initiative (GTRI), Fuel Thermo-Physical Characterization Project. The Fuel Thermo-Physical Characterization Project is tasked with analysis of irradiated Low Enriched Uranium (LEU) Molybdenum (U-Mo) fuel element samples to support the GTRI conversion program. Sample analysis may include optical microscopy (OM), scanning electron microscopy (SEM) fuel-surface interface analysis, gas pycnometry (density) measurements, laser flash analysis (LFA), differential scanning calorimetry (DSC), thermogravimetry and differential thermal analysis with mass spectroscopy (TG /DTA-MS), Inductively Coupled Plasma Spectrophotometry (ICP), alpha spectroscopy, and Thermal Ionization Mass Spectroscopy (TIMS).

The project will utilize existing Radiochemical Processing Laboratory (RPL) operating, technical, and administrative procedures for sample receipt, processing, and analyses. Test instructions (TIs), which are documents used to provide specific details regarding the implementation of an existing RPL approved technical or operational procedure, will also be used to communicate to staff project specific parameters requested by the Principal Investigator (PI). TIs will be developed, reviewed, and issued in accordance with the latest revision of the RPL-PLN-700, RPL Operations Plan. Additionally, the PI must approve all project test instructions and red-line changes to test instructions.

\subsection{Sample Description}

The primary research scope is to determine the thermo-physical properties as a function of burn-up, specifically the thermal conductivity by measuring the thermal diffusivity, density, and heat capacity of an irradiated uranium molybdenum foil within zirconium and aluminum cladding, shown in Figure 2 .. Physical examination of fuel elements may also be performed to determine average thickness of cladding, foil, non-homogeneous fuel/zirconium and zirconium/aluminum interface, and porosity.

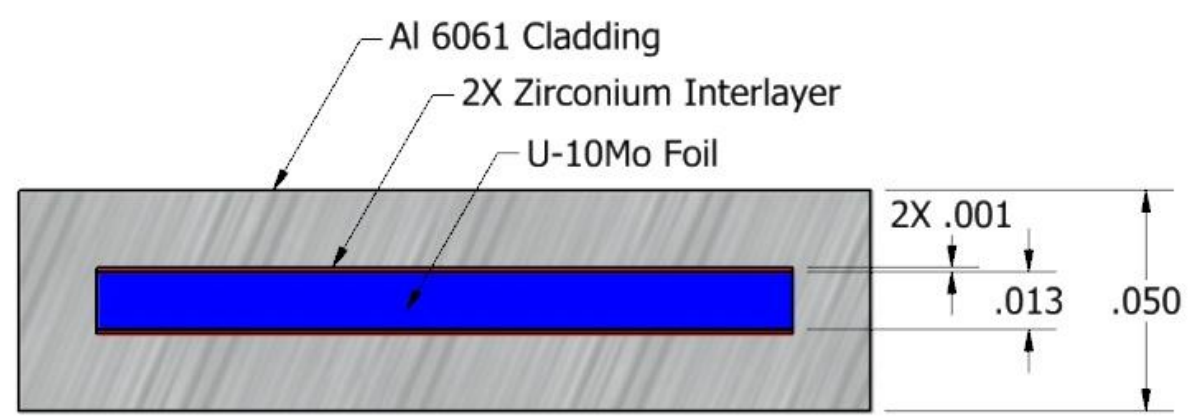

Figure 2.0. Typical Fuel Foil Cross-Section (dimensions are in inches) 


\subsection{Sample Path}

Each segment that is received by Pacific Northwest National Laboratory (PNNL) will be delivered to the RPL Shielded Analytical Laboratory (SAL). Once in SAL the segment will be transferred to the hot cell, sectioned, and distributed for Thermal Analyses or Fission Gas Analyses (shown in Figure 3.0). The samples for Thermal Analyses and Fission Gas will be obtained from separate segments. Once all analyses have been performed the samples will be transferred back to the SAL hot cells and stored pending approval from the PI for collective disposal. Each of these processes is described in more detail in the following sections.

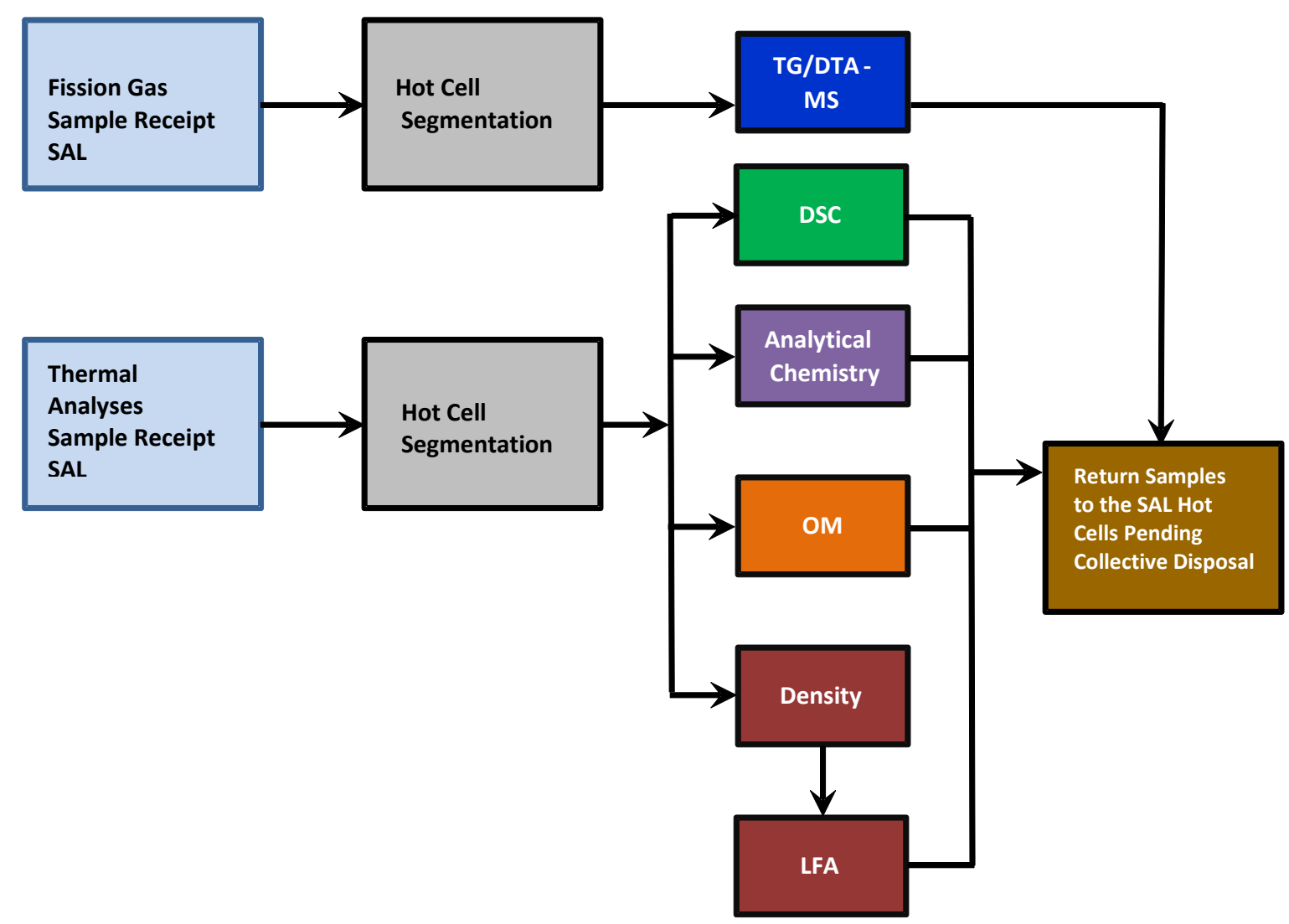

Figure 3.0. Flow Diagram for Sample Paths and requirements for U-Mo fuel elements 


\subsection{Sample Receipt - Shielded Analytical Laboratory}

The pathway and criteria for segment receipt in SAL are depicted in Figure 3.1. Upon notification of shipping intent from Idaho National Laboratory (INL), PNNL should be notified of the date the shipment will leave INL, the dose rate of each segment and of the outer container, the number of segments being shipped, the identification (ID) label on the segments, segment size, and the expected arrival date at PNNL. INL should also mark the segment identification number on the fuel segment.

Prior to receipt of the segments, PNNL will enter the inventory for each item into the Radioactive Materials Tracking (RMT) System, which will verify the segments may be accepted in the Shielded Analytical Laboratory and associated hot cells. Once received by PNNL and a RPT has performed removable contamination and dose surveys of the shipping vehicle and outer container, the segment will be transported from the shipping vehicle into SAL, where the segment will be removed from the shipping container and transferred into SAL hot cell \#1. Once in the hot cells, a test instruction will provide instructions for performing segment verification activities such as count, IDs, size, weight, and video recording as requested by the PI. This information will be used to confirm the accuracy of the INL shipping records. Once sample verification activities are complete, the segment will be transferred to the SAL storage hot cell or cell \#6 for sectioning. 


\section{Sample Receipt and Transfer to SAL Hot Cell \#1}

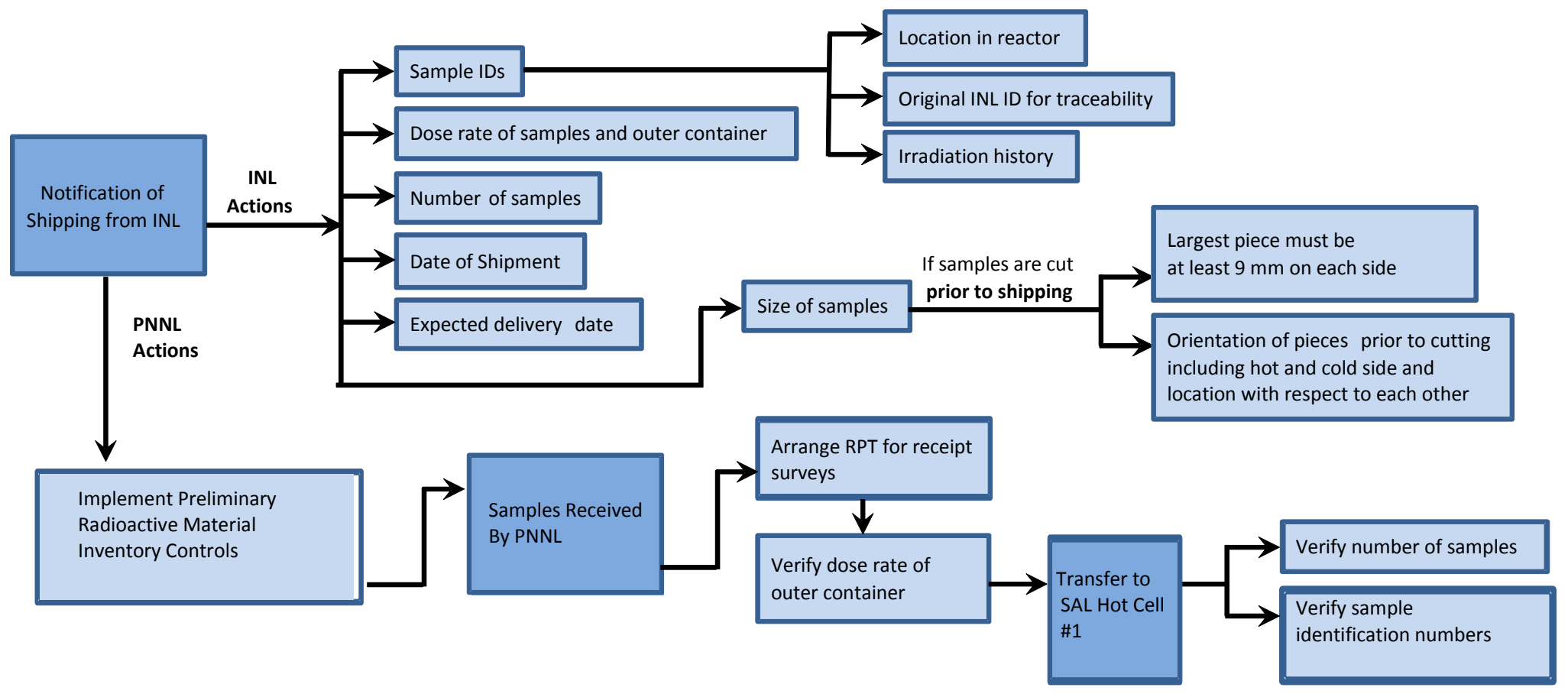

Figure 3.1. Path and criteria for sample receipt and transfer to SAL Hot Cell 


\subsection{Sample Sectioning}

Sectioning will occur in SAL hot cell \#6 using a low speed saw. The preferred environment during sectioning is an inert atmosphere to reduce oxidation of the uranium metal, which may result from the heat of friction generated by the saw.

The outline for segment division is shown in Figure 3.2A and Figure 3.2B and based on PNNL receiving approximately 1 inch x 0.5 inch segments. A test instruction specific to each segment, developed by the PI and research and hot cell staff members, will outline the sectioning configuration for each as received segment. In addition, the TI will provide instructions for obtaining dimensional and weight measurements and video documentation as well as communicate the dimensional tolerances if required for a specific analysis for each sample produced from segmentation. 
Samples for LFA, pycnometry, OM, DSC, and analytical chemistry

Dimension given are length (vertical) by width (hortizontal)

Each cut is assumed to take $0.5 \mathrm{~mm}$

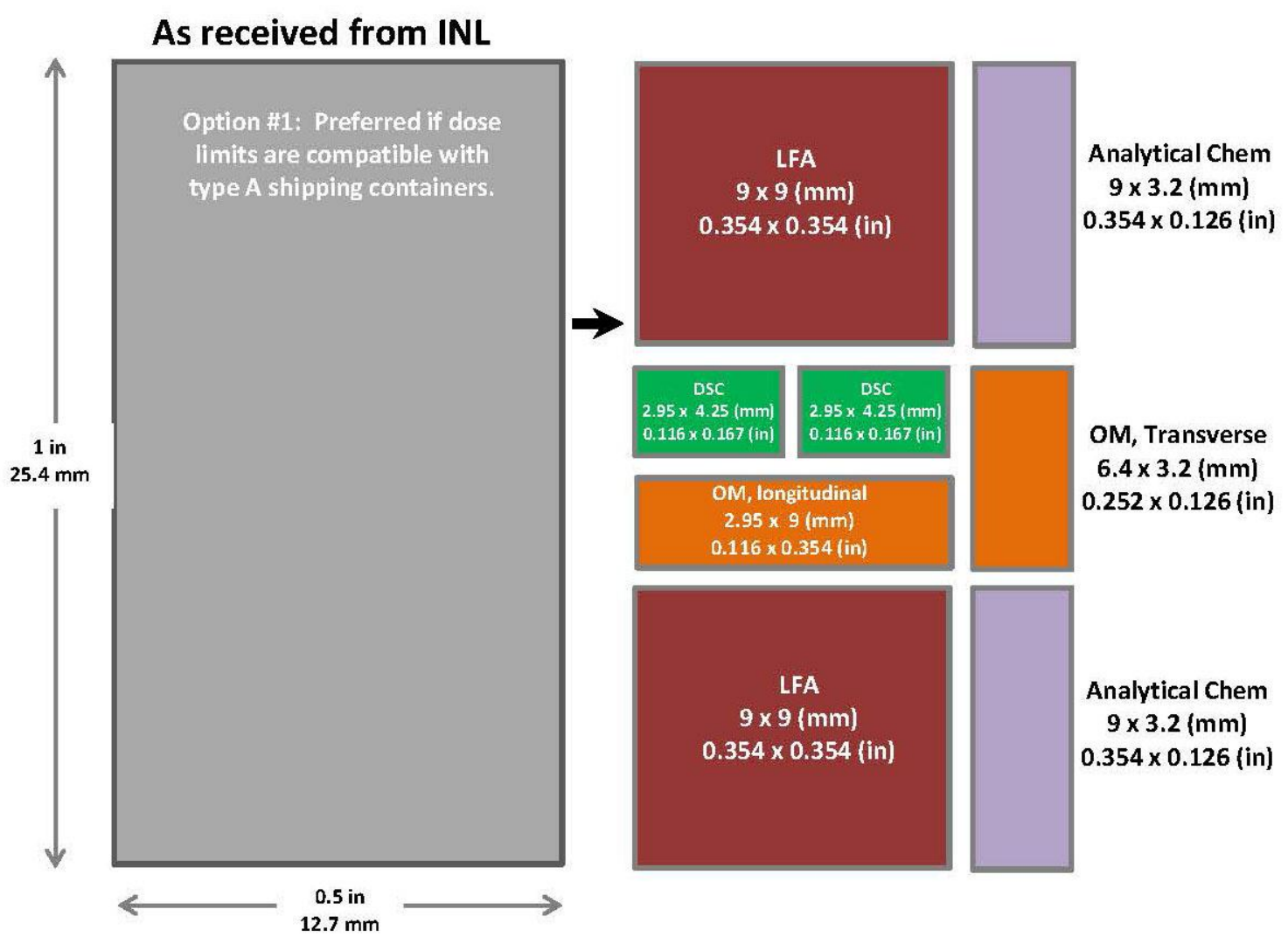

Figure 3.2A. Segmentation of samples for LFA/density, OM, DSC, and analytical chemistry 


\section{Samples for TG/DTA-MS}

Each cut is assumed to take $0.5 \mathrm{~mm}$

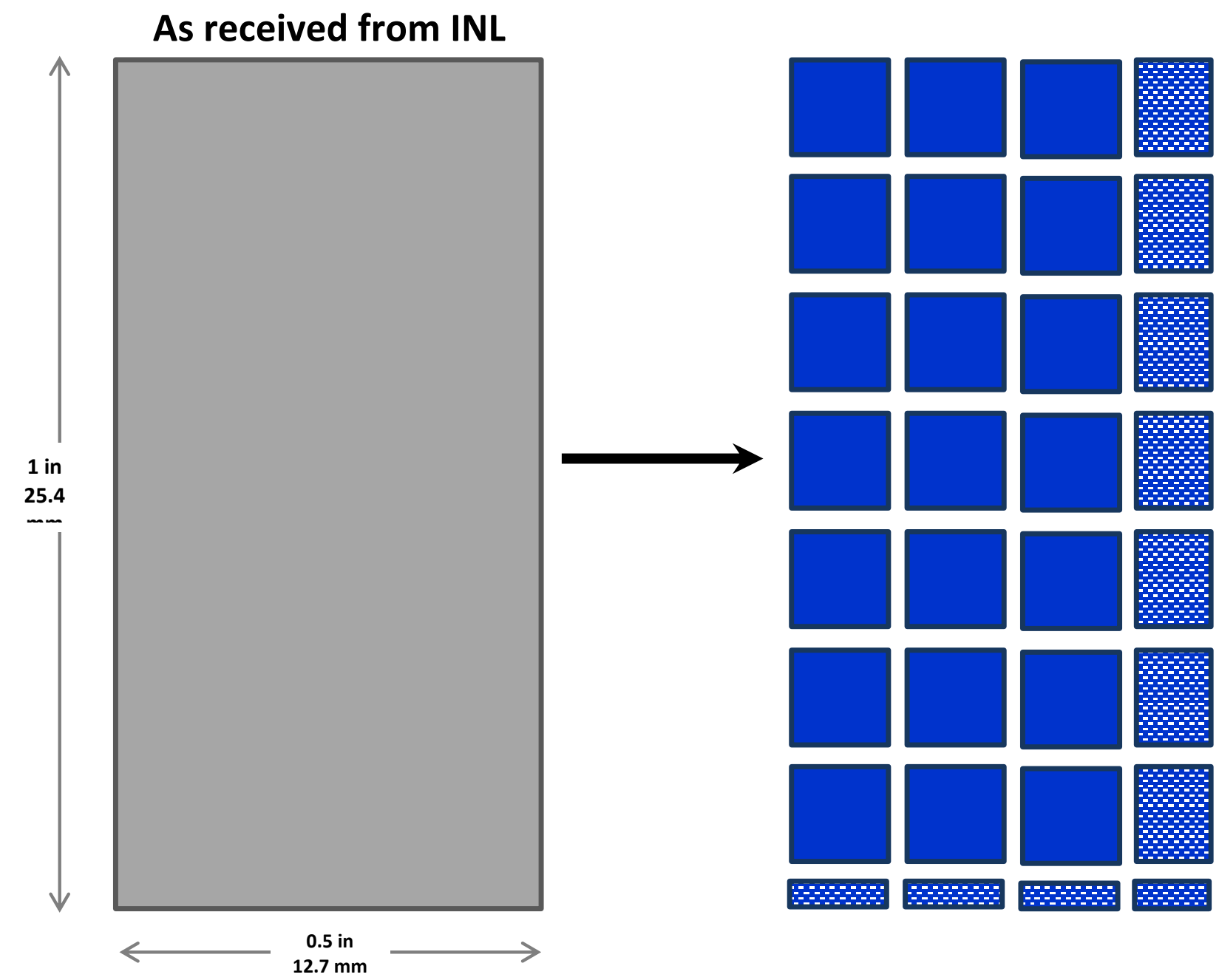

Figure 3.2B. Segmentation of samples for TG/DTA-MS 


\subsection{Sample Management and Identification}

General sample management instructions for RPL are addressed in RPL-PLN-701 RPL Basic Work Control. Project TIs will be provided with specifications for labeling and storing samples. RMT will be used to bound the radioactive material inventory in the hot cells and associated laboratory spaces. The individual sample locations will be tracked in the GTRI UMo laboratory note book located in the SAL operating gallery.

Each as received segment from INL is expected to be labeled as "A", "B", "C", or " $D$ ". The planned approach is to label sectioned samples with letter designator " $T$ " for thermal analysis, the segment id A, $\mathrm{B}, \mathrm{C}$, or $\mathrm{D}$ then the specific analysis followed by the sample number 1 or 2 . Therefore, each sectioned sample will contain string of alpha-numeric designators that trace the sectioned sample back to the segment number and sample location with respect to the reactor flux. An example of the naming convention for thermal analyses samples is in Figure 3.3A. 
Samples for Thermal Analyses, LFA/Density, DSC, OM, Analytical As received from INL

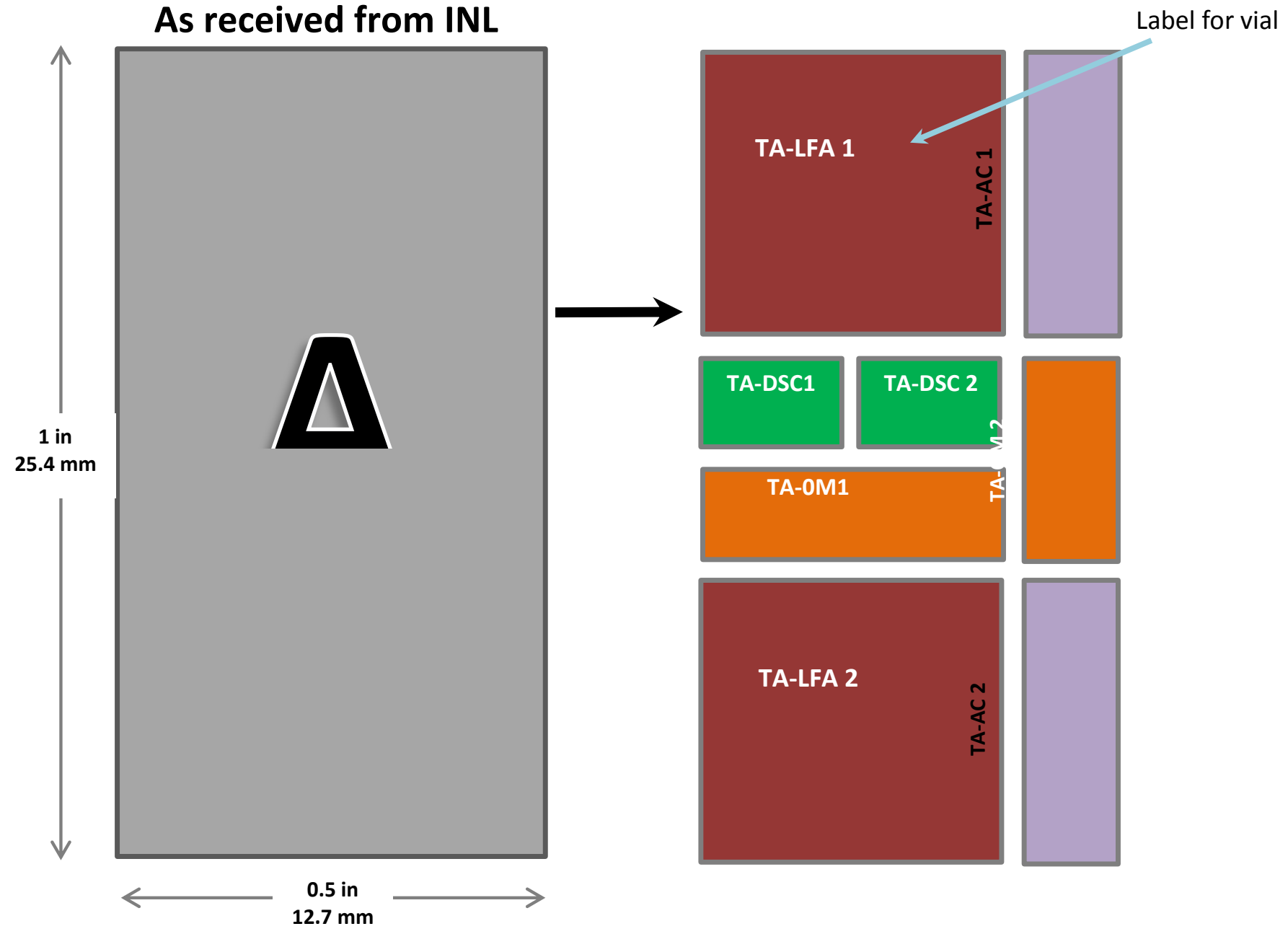

Figure 3.3A. Planned nomenclature for LFA/density, OM, DSC, and analytical chemistry samples 
The segment used for Fission Gas will also arrive from INL labeled with the segment id A, B, C, or D. The planned approach is to label vials containing sectioned samples with the letter designator " $F$ " for Fission Gas, the segment id A, B, C, or D then the specific analysis followed by the sample number 1 through 32 that trace the sectioned sample back to the segment number and sample location with respect to the reactor flux. An example of the naming convention for Fission Gas samples is depicted in Figure 3.3B.

\section{Samples for Fission Gas, TG/DTA-MS}

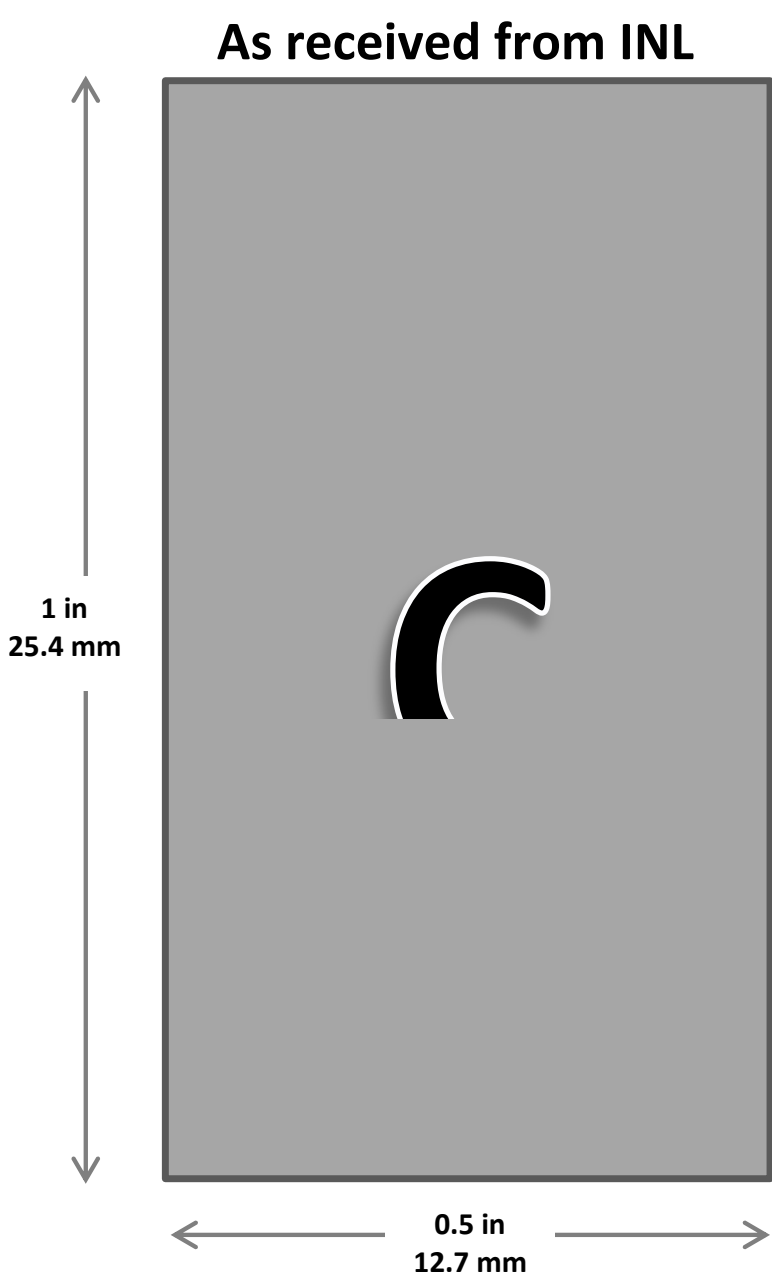

= Samples

= Spare Samples
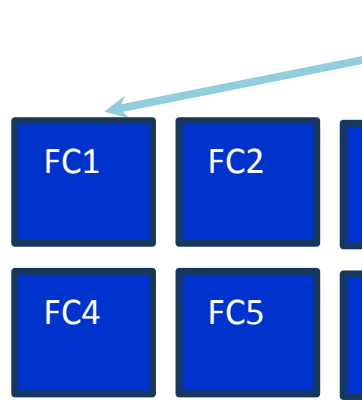

\section{FC3}
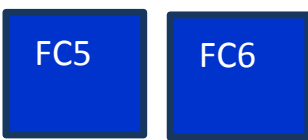

Label for vial
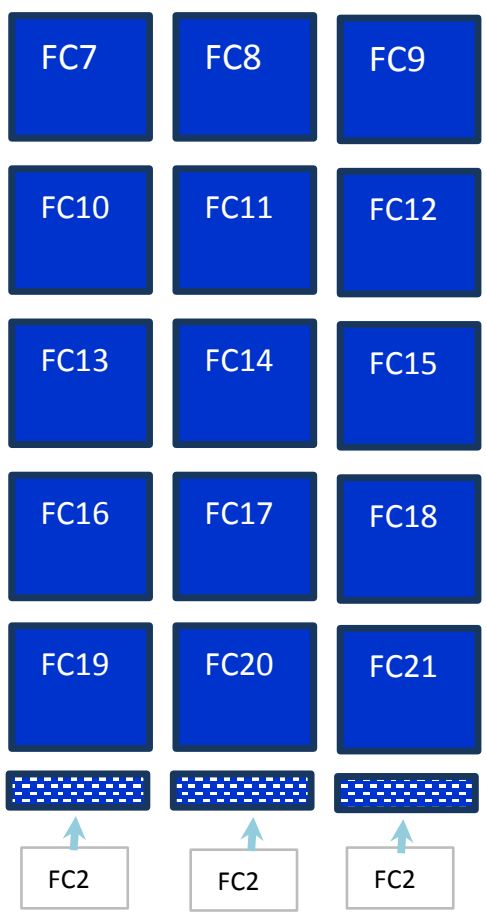
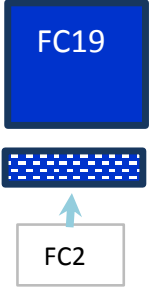
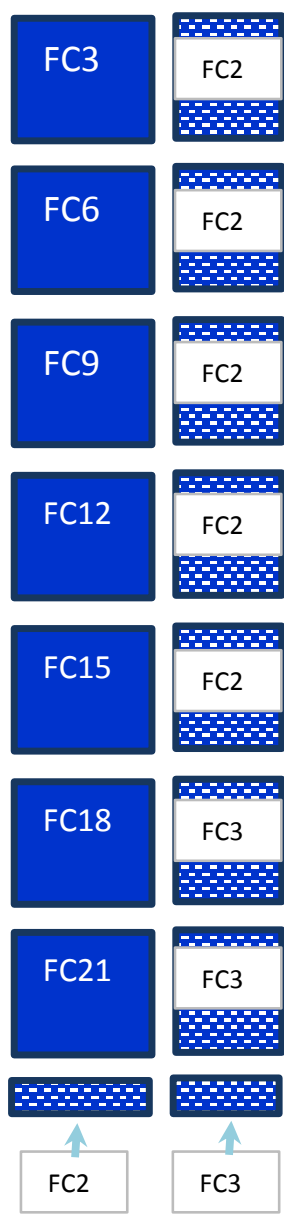

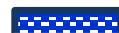

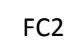

$\alpha+\alpha$

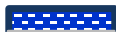
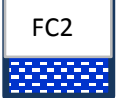

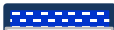

FC2

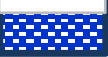

a

FC2

우요

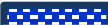

FC3
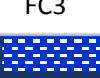

A...............
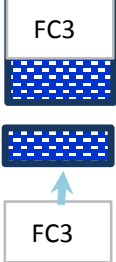

Figure 3.3B. Planned nomenclature for TG/DTA-MS samples 


\subsection{Analytical Chemistry Samples}

Two samples are designated for analytical and radiochemistry analyses. The analyses performed will determine the elemental content of the dissolved fuel and the isotopic concentration and ratios of the $\mathrm{U}$ and $\mathrm{Pu}$ in the dissolved fuel. The dissolution and analysis processes are depicted in Figure 3.4. Prior to dissolution, the samples will be weighed. After dissolution, the remaining, undissolved cladding will be dried and weighed. The undissolved cladding will be retained in case additional analysis of the cladding is requested. Subsamples of the dissolved fuel solution will then be loaded out of the hot cell and sent for analyses. The total $\mathrm{U}$ and Mo content of the dissolved fuel will be determined by inductively coupled argon plasma-optical emission spectroscopy (ICP/OES). The isotopic U (U-235 and U-238) and Pu (Pu238 and $\mathrm{Pu}$-239/240) content of the dissolved fuel will be determined by chemical separation of the $\mathrm{U}$ and $\mathrm{Pu}$ from the digestate, followed by alpha energy analyses (AEA). The $\mathrm{U}$ and $\mathrm{Pu}$ isotopic ratios will be determined by thermal ionization mass spectrometry (TIMS). Any unused sample solution in the analytical laboratory will be disposed of through the normal waste streams (unless the sample dose rate necessitates the need to return un-used sample fractions to the hot cell). All analyses results and required supporting documentation will be reported to the project and included in the project records. 


\section{Analytical Chemistry Samples}

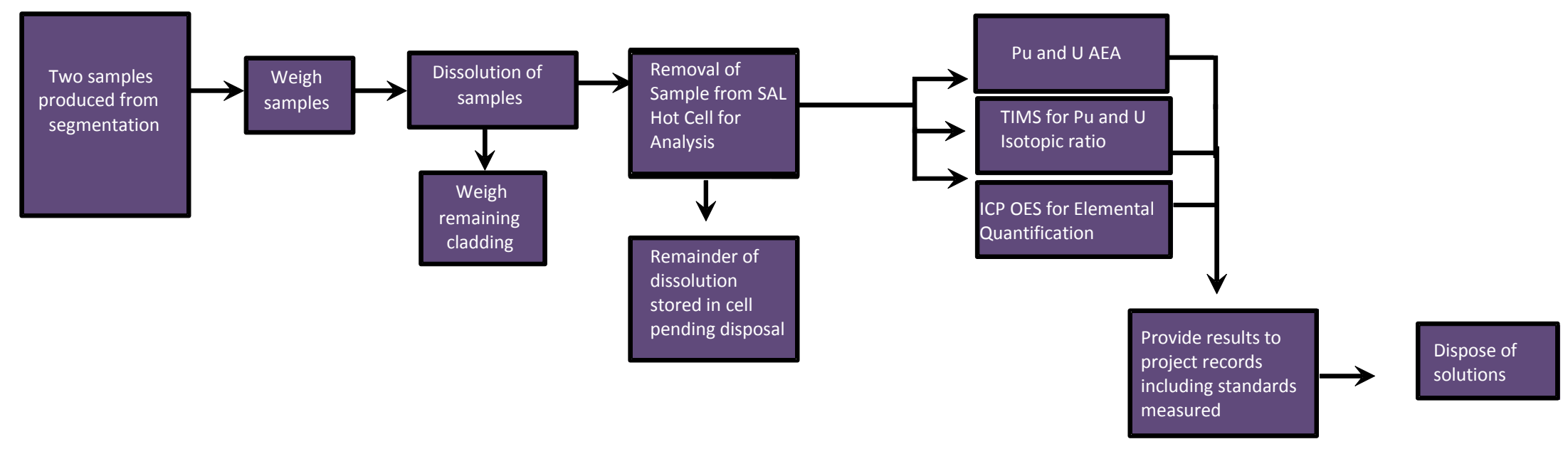

Figure 3.4. Path and criteria for analytical chemistry samples 


\subsection{Optical Microscopy Samples}

Two samples are designated for analysis by OM, and will follow the path depicted in Figure 3.5. Prior to transfer to the Isotope Separation Hot Cell in which the OM resides, the sample will be prepared for analysis by mounting the sample in epoxy and polishing with a 1 or $0.25 \mu \mathrm{m}$ grit polishing compound. After polishing, the sample may be further segmented. Orientation must be maintained during and after segmentation so an orientation mark will be applied by the Shielded Facilities Operations (SFO) Nuclear Operations Technicians, using manipulators and a marker, along the longitudinal side edge of the as received sample directly prior to sectioning. The OM analysis will visually examine the sample and report thickness of the layers. If the dose rate of the prepared sample is $<500 \mathrm{mrem} / \mathrm{hr}$, the sample may also be analyzed by scanning electron microscopy (SEM) if approved by the PI. If SEM analysis is possible this will also produce visual and thickness of layers. In addition energy dispersive spectrometry (EDS) analysis of composition may be performed. These results can be compared to and combined with the OM results to improve accuracy of measurements. All QA records, including standards measured, associated with this information should be provided for project records. At the conclusion of analysis, the sample will be transferred back to SAL hot cells \#1 - \#6 for storage and/or disposal. 


\section{OM Samples}

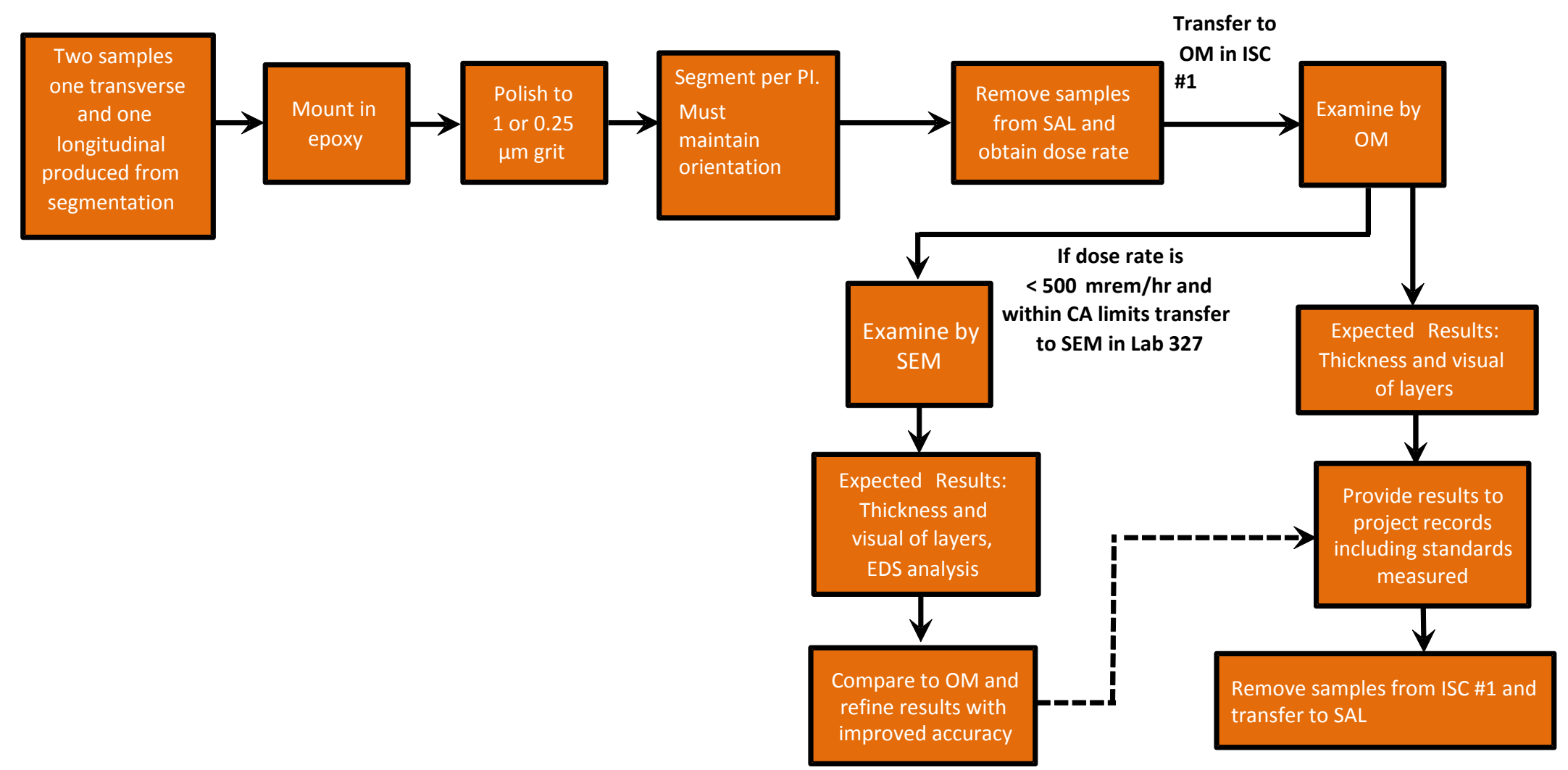

Figure 3.5. Path and criteria for OM samples 


\subsection{Density/LFA Samples}

Two samples are designated for analysis by gas pycnometry (density) and LFA. The sample path and criteria for the density and LFA samples are shown in Figure 3.6, both the pycnometer and LFA will use the same samples. The density of the samples will be measured by pycnometry, weighed, and dimensions obtained using a micrometer. This data will be provided to project records along with standards measurements. Once the density is measured the samples will be transferred to Process Development Cell \#2 (PDC\#2) at which time a dose rate on the sample will be obtained. Measurements by LFA will then be taken in PDC2. All results from the LFA along with standards measurements should be provided to project records. At the conclusion of analysis, the samples will be transferred back to SAL hot cells \#1 - \#6 for storage and/or disposal. 


\section{Density/LFA Samples}

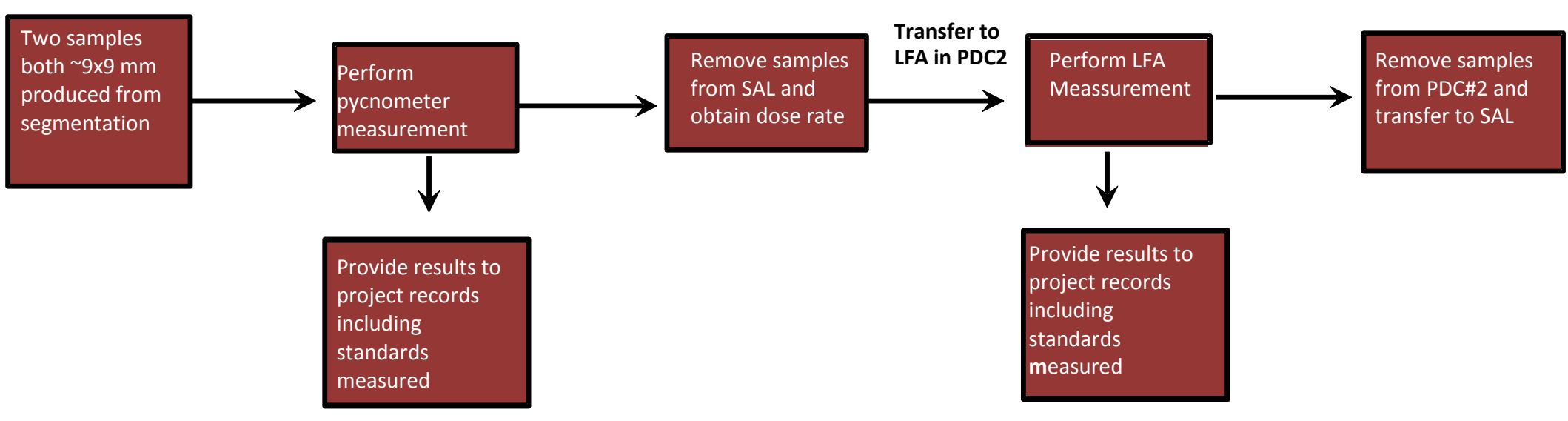

Figure 3.6. Path and criteria for density and LFA samples 


\subsection{DSC Samples}

Two samples for DSC analysis will be produced during sectioning. These samples must measure approximately $2.95 \times 4.25 \mathrm{~mm}$ to fit in the DSC sample pans. The sample path and criteria for the DSC samples are shown in Figure 3.7. The DSC samples will be analyzed in SAL hot cell \#6. All results from the DSC along with standards measurements should be provided to project records. At the conclusion of analysis, the samples will be stored pending further analysis and/or disposal

\section{DSC Samples}

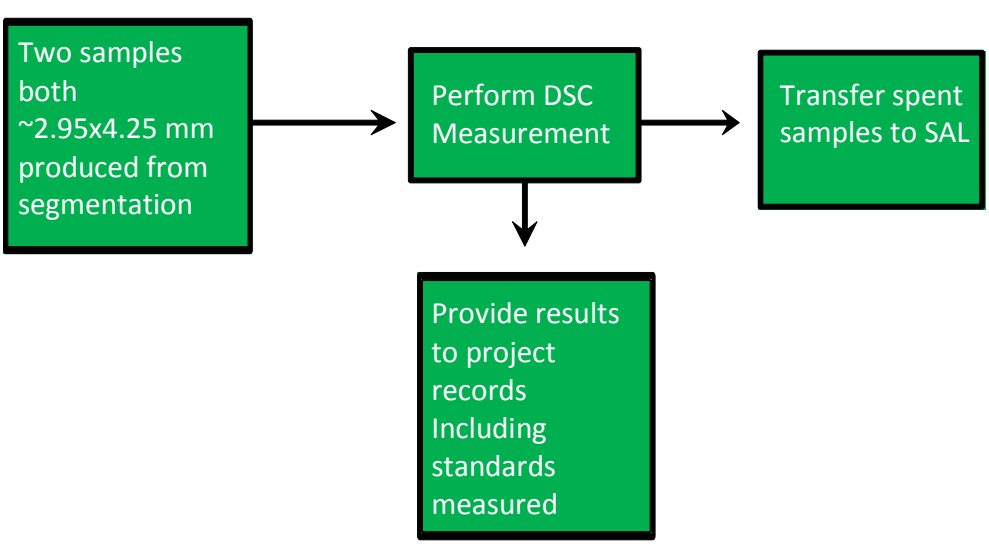

Figure 3.7. Path and criteria for DSC samples 


\subsection{TG/DTA-MS Samples}

A grid of samples for DTA/TG-MS analysis will be produced during segmentation. These samples must be equal to or less than $3.5 \mathrm{~mm}$ on each side to fit in the sample pans. The sample path and criteria for the DTA/TG-MS samples are shown in Figure 3.8. The DTA/TG-MS samples will be removed from SAL and transferred to Process Development Hot Cell \#1 (PDC\#!)1, at which time a dose rate of the sample will be obtained. Measurements by DTA/TG-MS will then be taken in PDC\#1. All results from the DTA/TG-MS along with standards measurements should be provided to project records. At the conclusion of analysis, the samples will be transferred back to SAL hot cells \#1 - \#6 for storage and/or disposal. The TG/DTA furnace tube is equipped with a removable metal liner designed to capture volatile fission products from the irradiated fuel. The PI may request the liner to be removed from the TG/DTA furnace, loaded out of the hot cell, and transferred to the analytical lab for radionuclide analyses. A cold trap assembly has been installed in-line between the TG/DTA furnace tube exhaust and the mass spectrometer system which is designed to remove any fission products not previously captured on the furnace liner. The cold trap assembly may also be removed from the hot cell and sent to the analytical laboratory for radionuclide analyses.

\section{TG/DTA-MS Samples}
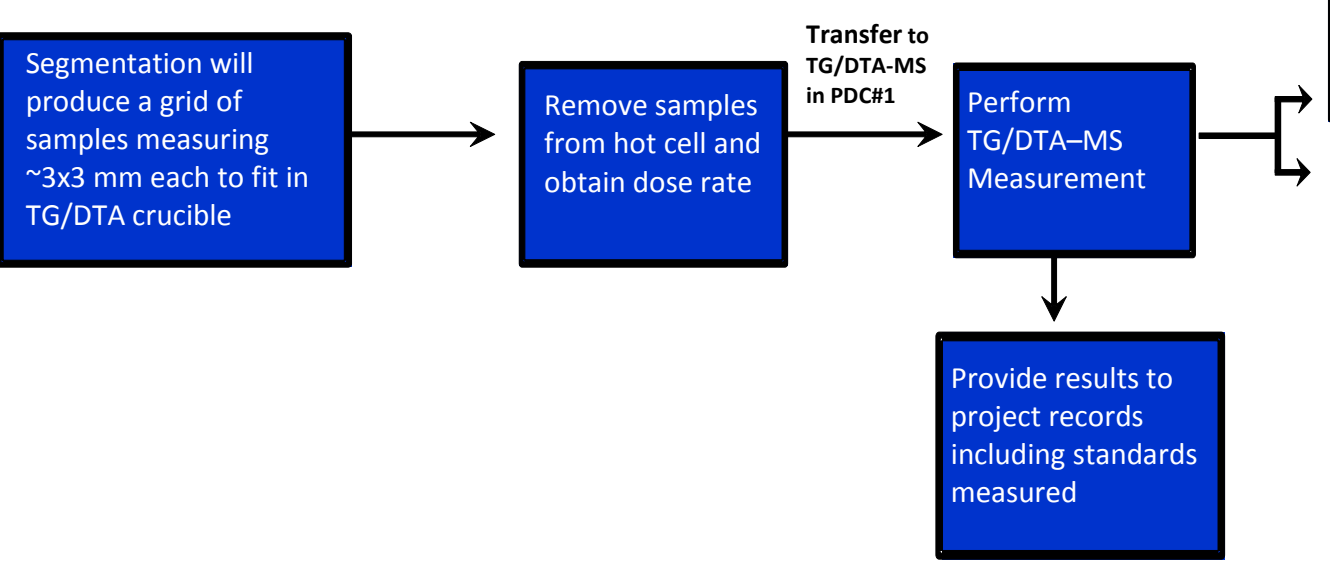

Remove spent

samples from

PDC\#1 and Transfer

to SAL

Remove Liner/Cold

Trap from PDC\#1

for analysis

Provide results to

project records

including standards

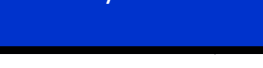

measured

Provide results to

project records

including standards

measured

Figure 3.8. Path and criteria for DTA/TG-MS samples

\subsection{Disposal of Samples}

The fines generated from sectioning will be collected in SAL hot cells \#1 - \#6, and all analyzed samples will be returned to SAL for collective disposal, with the possible exception of the $\mathrm{U}$ and Mo samples as they may be discarded as typical laboratory generated radioactive waste. 


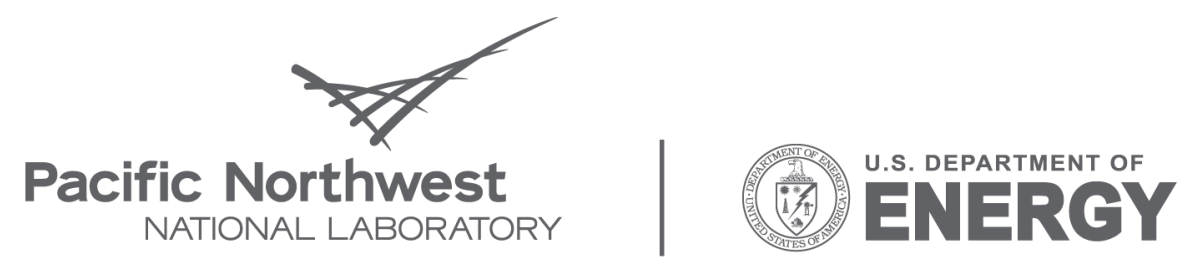

Proudly Operated by Battelle Since 1965

902 Battelle Boulevard

P.O. Box 999

Richland, WA 99352

1-888-375-PNNL (7665)

www.pnl.gov 